\title{
Cave sanctuaries in the Bronze Age Cyclades? New evidence from the island of Paros, Greece
}

Fanis Mavridis ${ }^{1, *}$

Recent research at two cave sites on the island of Paros have yielded some of the first evidence for the ritual use of caves in the Cyclades during the second millennium $B C$.

\section{Introduction}

Current field research in caves on the island of Paros (Figure 1) adds new and important evidence for Bronze Age activities beyond the traditional settlement sites in the central Cycladic region. Until recently, Zas Cave on the island of Naxos was the best-known, systematically excavated cave in the Cyclades. This site yielded important finds dating mainly to the Late Neolithic and Early Cycladic phases (fifth to third millennia BC) (Zachos 1987: 696). Later Bronze Age material is also present (Barber 2017). Salvage excavations at the Antiparos cave produced Late Neolithic and occasional Early Cycladic material (Mavridis 2010). Likewise, recent fieldwork in cave sites on the island of Irakleia provided evidence for Bronze Age cave use (Mavridis et al. 2018). It seems, therefore, that caves were used extensively in the Cyclades from the Late Neolithic onwards; their Bronze Age use, however, is only starting to be appreciated (Figure 2).

\section{Use of caves in the Bronze Age Aegean}

The Cyclades are less well known than other Aegean regions for the prehistoric use of caves, despite the difficulties in identifying the nature of activities in each case. Several caves on mainland Greece have yielded pottery and figurines dating to the Early, Middle and Late Bronze Ages. Burials in caves during the Early and Late Bronze Age are also known (e.g. Lolos 2000: 29-32; Mavridis \& Tankosic 2016). Possible ritual activities have been suggested at Panormos Cave in the town of Ithaka, and at Corycian Cave at Delphi (Benton 1938/1939; Lerat 1984). Beyond Crete, Daskalio (Vathy) Cave on the Dodecanese island of Kalymnos is suggested as having a sacred nature (Benzi 2011: 20).

On Minoan Crete, caves were used as burial grounds, ritual places or shelters, while also serving other practical purposes (see Platon 2013: 155). Minoan ritual use of caves is considered to have peaked in the Middle Minoan III period (Rutkowski 1986: 59; Faro 2013: 169), between $c .1750 / 1700$ and 1700/1675 BC. Cretan caves have yielded bronze

1 Ephorate of Palaeoanthropology and Speleology, Hellenic Ministry of Culture and Sports, Ardittou 34B, 11636 Athens, Greece

* Author for correspondence (Email: fanismavridis@gmail.com)

(C) Antiquity Publications Ltd, 2018 ANTIQUITY 92363 , e4 (2018): 1-5 


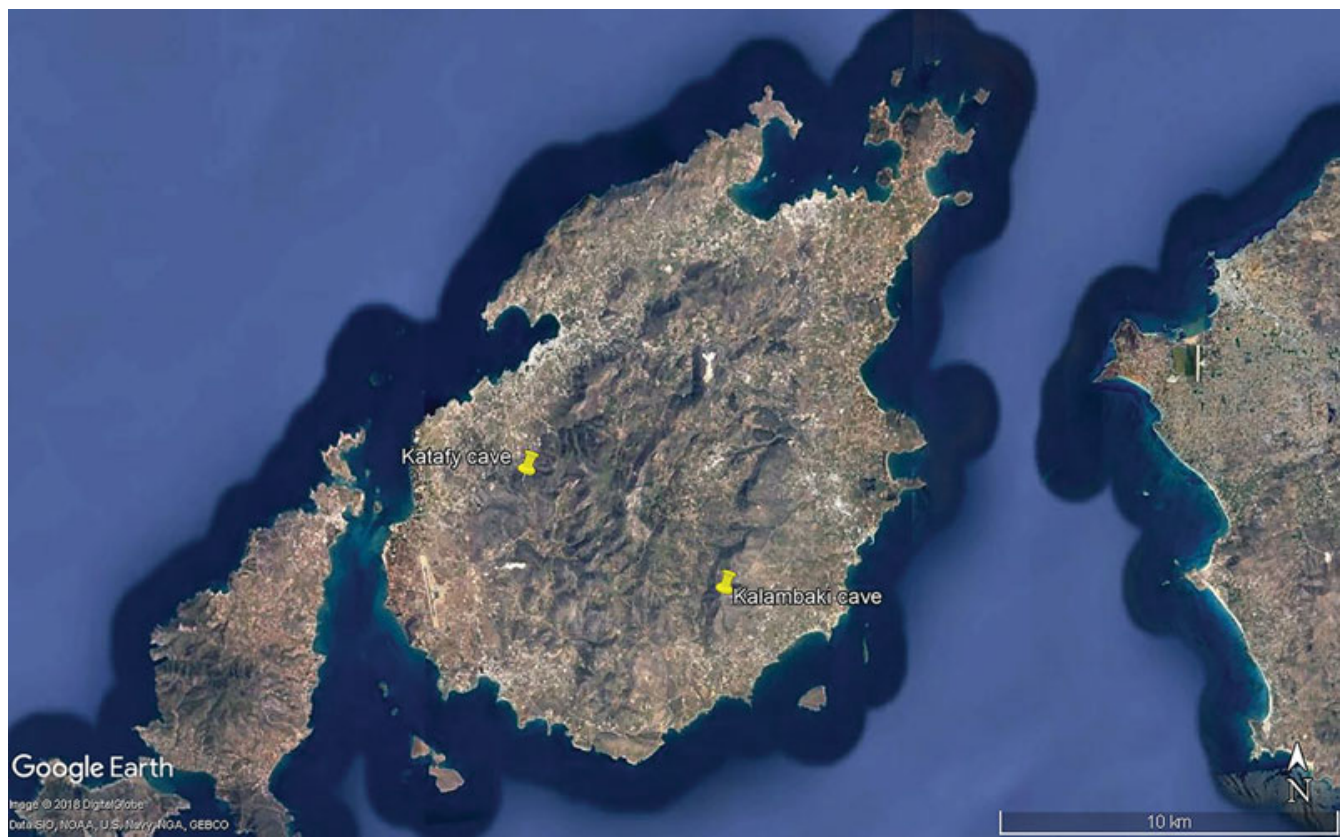

Figure 1. The location of Katafy and Kalampaki Caves on Paros Island (ㄷ Google Earth).

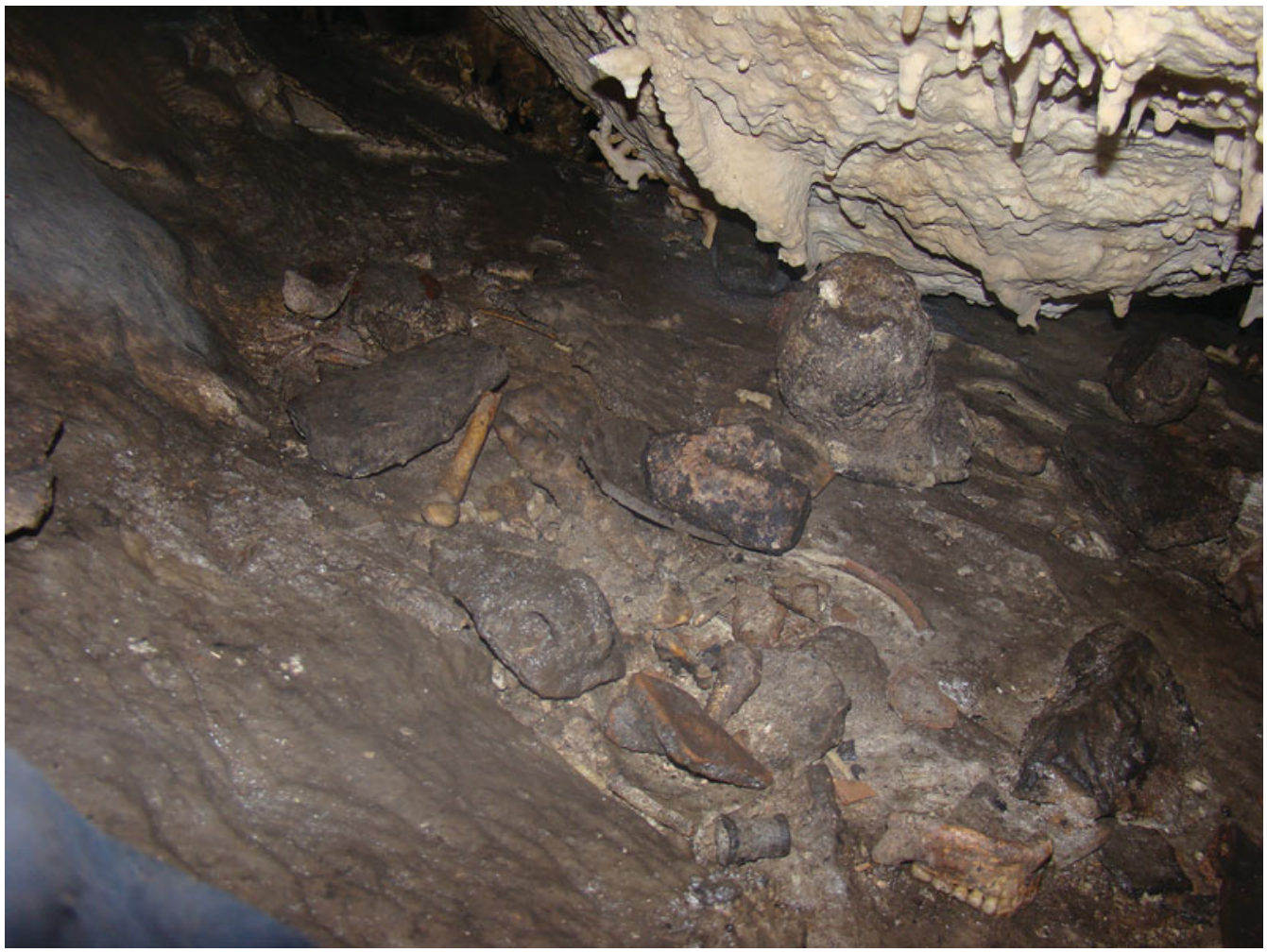

Figure 2. Prehistoric pottery and human bones in Kalampaki Cave (photograph by F. Mavridis).

(C) Antiquity Publications Ltd, 2018 


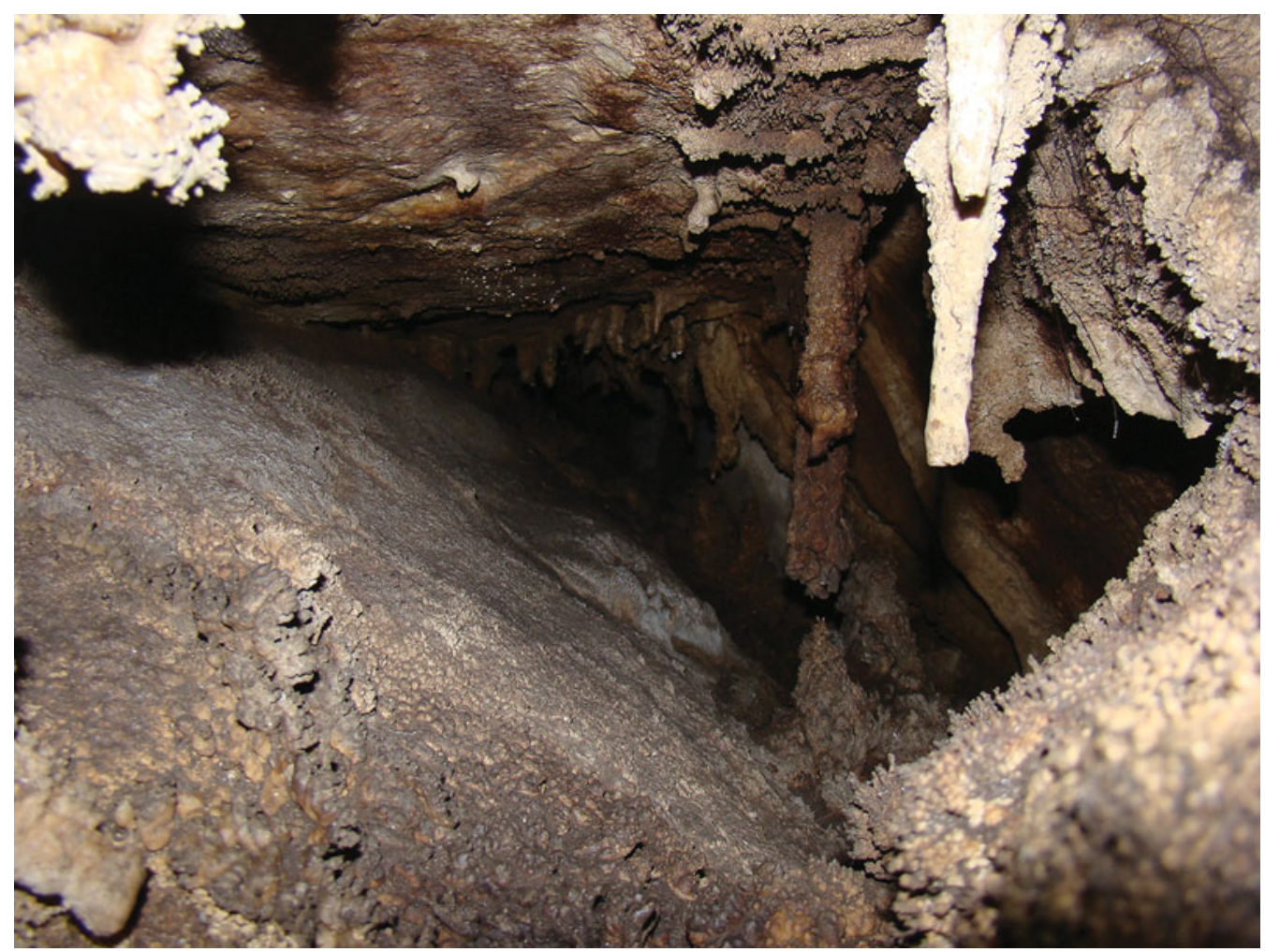

Figure 3. Kalampaki Cave, first chamber (photograph by F. Mavridis).

anthropomorphic and zoomorphic figurines, items of personal status and identity (e.g. weapons and jewellery), and cult symbols, such as double axes (Platon 2013: 156). Pottery seems to be the most widely attested type of material and includes vases with pierced bases used for libations, as well as cooking pots, jugs, spouted jars, small-sized oval-mouth jars, cups and bowls (Tyree 2013: 179-80; Koehl 2006: 334). Recent finds from the island of Paros add new evidence to the overall discussion of the Minoan influence in the Aegean.

\section{Kalampaki and Katafy Caves, Paros}

Kalampaki, or the Cave of the Demons, lies on the north-western end of the central mountain of Paros (Profitis Ilias) at an altitude of $200 \mathrm{~m}$, close to the village of Marpissa (Figures $1 \& 3$ ). The cave has a low entrance followed by a narrow passage, which leads to a first chamber with an average height of $1.5 \mathrm{~m}$ and impressive stalagmitic columns. The second chamber was reached after a $25 \mathrm{~m}$-deep descent. The cave produced evidence of use from the Late Neolithic to the Early Cycladic I-III (fifth to third millennia BC). Of special interest are the finds of Middle Cycladic (e.g. Minyan and painted wares), Late Cycladic I-II and Mycenaean dates. The different conical cups, some of which were found almost intact in the crevices of the second chamber, may indicate sacred use. This is also suggested by vases with pierced bases. Numerous seashells, animal bones and traces of burning were

(C) Antiquity Publications Ltd, 2018 


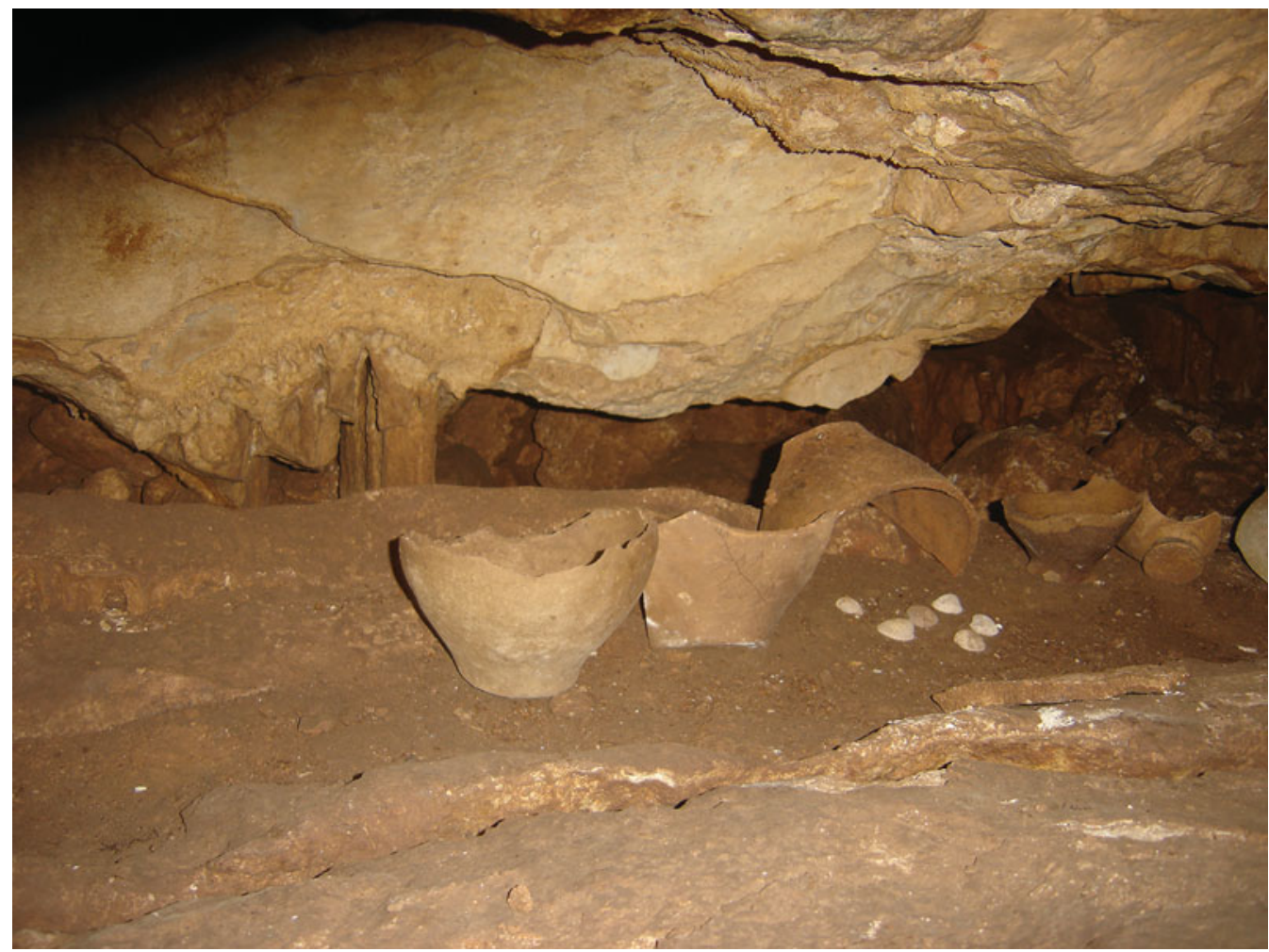

Figure 4. Bronze Age pottery and seashells in Katafy Cave (photograph by M. Perantinou and G. Anousakis).

also identified. Part of a human mandible located in a barely accessible location in the first chamber may suggest that the cave was used as a prehistoric burial ground.

Katafy Cave lies in the western part of Paros, on the mountain of Kavalos. At an altitude of $293 \mathrm{~m}$, the site overlooks the town of Paroikia. Katafy has a downward-sloping entrance leading to various corridors and chambers at different elevations. The deepest chambers, which are difficult to access, have concentrations of organic remains (human and animal bones, seashells and land snails) and traces of surface burning, along with pottery dated to the Late Middle Cycladic/Late Cycladic I phase (Figure 4). The pottery consists of conical cups, small-sized askoid vessels, cups, nippled/eyed ewers, oval-mouth pithoids and Melian bowls, among others. Although some of this material was produced locally, there is also pottery imported from other islands, including Crete. One bronze dagger and a seal-stone bead were also found at Katafy.

\section{Conclusion}

Recent research on Paros has yielded some of the first evidence to suggest that caves in the Cyclades were used for ritual practices during the second millennium BC. Fieldwork and systematic study of the retrieved archaeological material is currently in progress and will add much to the understanding of a unique, diverse assemblage of finds. Moreover, systematic

(C) Antiquity Publications Ltd, 2018 
comparison with related finds from other parts of the Aegean-especially Crete-will enhance our knowledge about contacts and interactions during this crucial phase of Aegean prehistory.

\section{Acknowledgements}

I would like to thank M. Perantinou, A. Marinopoulos, A. Darlas, Z. Tankosic, L. Kormazopoulou, D. Lambropoulos, L. Platon, A. Kotsonas, D. Karoutis and G. Anousakis for their help and support.

\section{References}

BARber, R. 2017. Keramike tis Mesis kai Ysteris Epochis tou Chalkou apo to spilaio tou $\mathrm{Za}$, in E. Kotsou \& E. Mermiga (ed.) Speira, Epistimoniki Synantisi prow timin tis Aggelikas Douzougli kai tou Kosta Zachou, Praktika: 49-54. Athens: TAP.

Benton, S. 1938/1939. The excavation in Ithaca III. The cave at Polis II. Annual of the British School at Athens 39: 1-51.

Benzi, M. 2011. Daskalio (Vathy), Kalymnos: a Late Bronze I sacred cave in the East Aegean, in W. Gauss, M. Lindblom, R. Angus \& K. Smith (ed.) Our cups are full: pottery and society in the Aegean Bronze Age, papers presented to J.B. Rutter on the occasion of his $65^{\text {th }}$ birthday: 13-24. Oxford: Archaeopress.

FARo, E. 2013. Caves in the ritual landscape of Minoan Crete, in F. Mavridis \& J.T. Jensen (ed.) Stable places and changing perceptions. Cave archaeology in Greece: 166-75. Oxford: Archaeopress.

Koent, R.B. 2006. Aegean Bronze Age rhyta. Philadelphia (PA): INSTAP.

LERAT, L. 1984. Époque Mycénienne, in École Française d'Athènes (ed.) L'Antre Corycien II: 3-25 (BCH Supplement 9). Paris: De Boccard.

Lolos, Y. 2000. To Spilaio tou Euripidi: tafiko mnemeio tis Mykinaikis Epochis. Eptakyklos 15: 29-32.
Mavridis, F. 2010. Salvage excavation in the cave of Antiparos, Cyclades. Prehistoric pottery and miscellaneous finds. A preliminary report. Aegean Archaeology 9(2007-2008): 7-34.

Mavridis, F. \& Z. TAnkosic. 2016. The Early Bronze Age burial deposits at the Ayia Triada Cave, Karystos, Euboea: tentative interpretations. Hesperia 85: 207-42. https://doi.org/10.2972/hesperia.85.2.0207

Mavridis, F., Ž. Tankosic \& A. Kotsonas. 2018. The Irakleia Caves Exploration Project and the importance of cave research for the archaeology of the Cyclades: a brief note, in E. Angliker \& J. Tully (ed.) Cycladic archaeology and research: new approaches and discoveries: 249-60. Oxford: Archaeopress.

Platon, L. 2013. The uses of caves in Minoan Crete. A diachronic analysis, in F. Mavridis \& J.T. Jensen (ed.) Stable places and changing perceptions. Cave archaeology in Greece: 155-65. Oxford: Archaeopress.

Rutкowski, B. 1986. The cult places of the Aegean. New Haven (CT): Yale University Press.

Tyree, L. 2013. Defining Bronze Age ritual caves in Crete, in F. Mavridis \& J.T. Jensen (ed.) Stable places and changing perceptions. Cave archaeology in Greece: 176-87. Oxford: Archaeopress.

Zachos, K. 1987. Naxos Spilaio Za. Archaeologiko Deltio 42 (1992; Chronika B2): 694-700. Athens: TAPA. 